\title{
Representation of Kashmiri Women in Naseem Shifaee's \\ Selected Poems
}

\author{
Dr. Rumana Ashraf \\ Cluster University \\ Srinagar, Kashmir, India \\ rumanaashraf93@gmail.com
}

\begin{abstract}
The paper undertakes examination of selected poems of Naseem Shifaee's translated in English by Neerja Mattoo by focusing on female identity . Literature looks at humanity with a questioning as well as affirmative gaze, disapproving and approving at the same time, reaffirming stereotypes as well as breaking them. Throughout ages narratives in Kashmir have revealed the inbuilt discrimination and biases against women. Cultural space for women is highly restricted in Kashmir. In spite of their marginalized position Kashmiri women made themselves heard , undeterred by established womanly restraints interrogated the patriarchal practices and refused to live in a culture of silence . Naseem Shifaee is a powerful women voice acclaimed internationally with the publication of her first poetry collection Darichi Matsrith (windows thrown open) highlighted the existing reality of women in contemporary Kashmir. The paper will explore the incongruity between the societal image of female poetic persona and her own instincts about her true nature .It will be argued how poetic persona is trapped in male allotted and confined space, persuaded to look at herself continually in terms of social conventions according to which women are denigrated by patriarchal supremacy .The bewildered state of mind leads her to undertake the obsessive search for her authentic self identity. She questions what if roles were reversed? In other two poems Naseem ques-
\end{abstract}


tions patriarchal traditions Naseem Shifaee assume the role of the medium in establishing female non being into self-realized person.

Keywords: Patriarchy, Kashmir, Women, Culture, Power, Language

This above all,to refuse to be a victim. Unless I can do that I can do nothing.I have to recant ,give up the old belief that I am powerless and because of it nothing I can do will ever hurt anyone withdrawing is no longer possible and the alternative is death .

Margaret Atwood

Introduction

Throughout history women has always been the subaltern across cultural boundaries .Men need her ,love her, adore her and write about her but they do so in relation to their lives. In this respect women has always been the "Second sex" .To quote Virginia Woolf, "Imaginatively she is completely insignificant, she pervades poetry from cover to cover; she is all but absent from history." ${ }^{11}$ Her representation in history in other words defined 'negation'. It provokes many women writers to raise pertinent question against the gender based inequalities through their writing.

Naseem Shifaee an internationally known translated a noteworthy contemporary Kashmiri writer draws our attention to the deleterious dimentions of gender discrimination. Naseem began her literary career with two collections of poems " Darichi Mutsrith" and "Na Chai Na Aks". She has been translated in English and many Indian languages. Her poems are honest explorations of female self and the roles women are offered in traditional Kashmiri society. Her poetry explores the silent and hidden operations of gender and conflict its politics.

Kashmir has a rich tradition of women poets. Lalded a $14^{\text {th }}$ century poet heralded the rich tradition of Kashmiri literature and was followed by Habba khatoon, Arnimal, Roop 
Bhawani and many other women poets. The timeless Lala became the collective consciousness of all Kashmiris.Habba khatoon in her poetry symbolized her life, romance, marriage and her separation from her husband who was imprisoned by Mughal rulers and subsequent pangs she faced throughout her life. Lalavakyas (wise sayings) of lalded and rich verses of poets rolled down to generations through word of mouth in Kashmiri language. In Kashmir wanvun and Rov are two genres of Kashmiri folk poetry in which women express their happiness and joy, despondency strain and stress. These songs are spontaneous outpouring of subjugated and deprived women of Kashmir and are invaluable documents of psycho-social life of Kashmiri women.

Naseem Shifaee became powerful voice of what may be called modern poetry in Kashmiri with her publication of "Darichi Mutsrith" ( windows thrown open ) which begins with a dedication to "all those women of Kashmir who wanted to open their hearts but could not find words to do so". Her poems provide comprehensive review of problems Kashmiri women confront in attaining full recognition and her feministic images focus on critiques of marriage ,motherhood, roles women are offered in Kashmir and personal distress faced by Kashmiris due to war -terrain situations. This paper examines Naseem Shifaee's feministic perspective as it emerges through three of her poems "Na Chaey Na Aks" (Neither shadow nor Reflection), “Baakh"(The Wail) and "Me Tog ne Zanun Me Tog ne Manun" ( I could never understand ) translated in English by Neerja Mattoo. Before proceeding a short definition of perspective by Susan Wendall draws our attention. Wendall defines "perspective is a pattern of thought .... of emotion, perception, expectation and motivation " 2 in other words it tells us how to think, perceive, expect and act. The fundamental goal of a feministic perspective says Maggi Humm is "to understand womens oppression in terms of race, gender, class and sexual preference and how to change it." ${ }^{3}$ Hence feminist principle is an uncomprising pledge and an antidote to all types of exploitation and oppression on women. 
Naseem's contribution to Kashmiri women does not lie simply in portrayal of suppressed and oppressed women but in her efforts to impart her a separate identity .In her poem "Na Chaey Na Aks" (Neither shadow nor Reflection) she articulates feminist quest for identity .The poem opens with a women's voice addressing her eternal disappointment to a male how he through ages have ignored her real self for empty pleasures of body.

Like always you came and stood at the door, saying nothing.

I .... Hear those flaming words that you always desire.

Your face alone I could not read, but the heat of your glance

I felt.

In my mind I knew that now when you come

It would be to listen to my breath alone

You would enter my ravaged breast like the breath of spring.

Poetic persona has been trapped in male confines and finds herself reduced to sex object by patriarchal structure .It is obvious from her account she is aware of the ambiguous status given to her by patriarchy as inherited from her past ,entrapped in a culture which has perceived her as a static image, a shadowy figure .She cries

You have no idea of the shapes you cast me in!

With these words signals a sense of crises in narrator as the narration has to enact the reconstruction of female identity. It is with lyrical fantasy her sweeping imagination she created female odyssey through ages and lashes out at social hegemony of males who use different strategies, make unjust rules and conditions to subjugate women. She evokes women referring to different ancient myths from Kashmir, history, religious establishments and includes verses from past women poets which are a part of collective memory of all Kashmiri women passionately to expose man's treatment towards women through ages.

I came like Lal and Weeping I rose at the waning of the night 
And woke you up, O mad one, and you learnt to speak.

I was Habba Khatun and called you my sky

Called myself the earth and you a cover over all my secrets !

Became your garden and asked you to come and taste its Wealth.

Tarry a while and remember -it was me that held you in

my lap and sang:

Should you come as Krishna, assuming numerous guises,

I will be Meera, with you at each step you take.

Should you pay heed to slander and ask me to prove myself,

I will stand in the flames and still keep chanting, 'Ram,

Ram'!

It was God who commanded, 'Go, inhale the fragrance from

that bottle .

To you a Messiah will be born,........

As mother of jesus, as Mary, how my value rose!

But abrasions of calumny followed my feet.

By calling women and women voices from past poetic persona bears witness to injustice patriarchy imposed on women and makes possible sympathy between these speakers across time, religious and cultural differences. Questioning power structures she asks 
Did you ever seek my consent?

Ah, the faces you gave me,

Was one of them actually mine?

Her own voice clamours with the voice of these women declaring solidarity of women and throwing power structures open to implement disarrangements which demand new judgements and solutions.

Resisting the male constructs she questions and challenges conventional assumptions about identity of women.

No, I am not like you, nor the image of me in your dreams

You are you-and I have my own being.

A separate being, that is what you must know.

The female voice in the poem denies and turns away from negative, subordinate submissive role and refuses to get washed away her selfhood, existence obliterated forever in conventional codes and categories." Rather than merely reinforce our given perceptions ,the valuable work of literature violates or transgresses these normative ways of seeing and so teaches us new codes of understanding"4 says Terry Eagleton . Poetic persona offers reversals turning the male territory back upon men. She leads him to take obsessive vision to feel her mutilated existence. She utters a challenge What if rules were reversed.

Come, go down in me and plumb my depth for a while

And see me-beyond beauty of form and face.

Come on, like Krishna descend from skies and worship me

Come on, as Rama Come and go through a trail by fire!

Lal saw me in Shiva's embrace and told you of it

It was me, me alone but still you did not know! 
Should you again abandon a Habba in midway somewhere.

If Knowledge dawns on you even today, then come,

.........Today for me alone, to stand by me, with me ,a real Adam!

Then I'II know that now you know -

That I am me, neither shade nor reflection.

These lines suggest by her empowering decision of leaving behind her patriarchal strategies she has freed herself from male domain thus acknowledging herself as an integrated ,individuated self aware person.

In the concluding lines a revelation is dawn upon her. The pronoun "I" in the poem is quiet significant she asserts herself into being when "I" and "me" are used in poem. Narrator recreates herself which was erased by patriarchy and reminds us of the fact patriarchy is retained in female consciousness. In search of herself narrator releases herself from conventional mirror image given to her and develops image for herself. A female self on equal footing with her male counterpart capable of reaching out to space which is beyond gender suggesting triumph of female power.

In her poem "Baakh"(The wail) Naseem exposes the ongoing tragedies of Kashmir voicing the grief which pervades the region and effects the lives of women in particular.The narration is a sentimental rendering of the trauma of a mother who has lost her son at the spring of his life .In the poem mother is shown a solitary figure taking refuge in seclusion.

Once upon a time there was a queen she would wait,

For her little princes to come.

A little hesitant, a bit afraid, 
She'd ask her neighbours, women like her,

"Are your children also out, still?

My own have quite forgotten their home!

She is the one to whom someone said something one day,

And her doors and windows were suddenly shut.

But in the dead of night, the ocean broke its bounds,

And the neighbours heard a long, unending wail-

"Do not die on me, you are so young!

"Do not die, your nails but barely henna-tipped"

By focusing on the cloistered existence of mother narrator suggests the circumscribed and submissive position women occupy in Kashmir. Her receding contact with the outer world leave the core of her integrity impaired. Narrator is attacking mores of society that believe in silence of women .It is her silence that leads to an ever widening gap between her and her neighbours Which is cognizant by shut doors and windows .She has dragged herself into complete darkness her failure to life.

Ocean is holder of water which is prime mover of life, she herself is holder of life. While commenting on image of ocean Neerja Matoo observes "The poet uses it as a symbol of the bounded world of suppression, repressed feelings and constricting restrains of propriety that women have been always had to live with" 5 The stunning abruptness to the reality of the untimely death of son that is too cruel for mother to face contributes to the melancholic atmosphere .Henna tipped nails reminds of nuptial ,henna is a symbol of marriage and reveals the tragic truth of Kashmir how promising youth who are at marriageable ages die and motherly instincts turn death of her son into something monumental there by validating the experi- 
ence of loss associated with Kashmiri mothers. Mother symbolizes mother land mourning over death of her youth yearning for peace, happiness and security.

Language is a primary medium into which we are born which moulds our perceptive medium which moulds our perceptive world Naseem Shifaee in her poem (MeTog ne Zanun) I could never understand questions language as a site of gender duality and inequality. Naseem is faced with the difficulty of articulating her experience in order to establish the worth of her distinctiveness but linguistic givens to her are male-oriented which do not take into account female existence. She confronts not merely as a female but also a female artist and questions the appropriation. Irigaray argues “women's oppression exists not only in the material, practical organization of economic, social, medical and political structures but also the very foundation of logos, reasoning and articulation .....in the subtle linguistic procedures and in the logical processes through which meaning itself is produced." 6 The division that marks the female narrator in the poem is her condition of being part of yet excluded from the hegemonic discourse so it becomes impossible for her to deliver a full throated expression.

I could never understand,

Never comprehend

Words I must Fashion,

Once fashioned, affix them,

Smeared with blood from the throat,

Dyed all red I must bring them,

Decked with flowers, relate them to all.

I could never understand,

Never comprehend.

In her poetic vision women have two alternative choices one is to appropriate language despite its being monopolized by men other is to reject it as a male instrument that 
merely re-inscribe women's marginality failing to determine any specificity of women's experience. What one finds in Shifaee's poem there is an interplay of two strategies where female narrator appears both inside and outside hegemonic structures.

When the neck is grabbed,

The throat must be offered,

When questions are asked,

No answers must you give.

If a thought arises,

Crush it within -

I could never understand,

Never comprehend.

Narrator feels unsure and struggles her appropriation of language is set against feeling of inadequacy and powerlessness in mastering it .To remain outside the hegemonic discourse involves greater risk so she does not challenge discourses of power, on the other hand her total appropriation of hegemonic discourses of power lead to negate her autonomy.

These pots were filled

With water strange.

Drink you must

For nectar it is.

But what if someone says,

"your throat is all blue"?

I could never understand,

Never comprehend.

The sense of non belonging of estrangement is very intense in poetic persona such a position brings into focus a split subjectivity. In the poem narrators oscillation between an 
appropriation and rejection is constantly present and seems infact necessary .She seems to imply language itself is a male construct and women have to enter it from outside in order to have any voice at all. Her negative position is suggested by her repetition of "I could never understand, Never comprehend". It indicated how on one hand appropriates language on the other hand sees language as an alien construct.

They said you are innocent,

A lesson you must learn-

The pen only flows

When speechless you are.

But what happens to me

When that deed is done?

I could never understand,

Never comprehend

Naseem questions women who allow themselves to be guided by the male perception and interpretation of the world , they have to free themselves from the clutches of male "Logic". The poem concludes with the image of Pen (Kalam) reflecting the split poetic persona and suggesting doublesided relation between language and speaking poet's doublesided relation to language duplicates the experience of women writer and her oblique marginal relation to hegemonic discourse .It is writing itself that can be seen as overcoming the contradiction and risk of dangerous identification.

\section{Conclusion}

Naseem Shifaee's poetry is committed to bring about changes in the lives of Kashmiri women. She advocates a change within not imposed from above in the form of laws and 
rules, she knows any freedom outside i.e. external ceases to have any meaning and strength unless it is reinforced by the inner freedom. 


\section{Works Cited}

Virginia Woolf,A Room of one's own:in Mary Eagleton ed.Feminist Literary Theory :A Reader London Basil Blackwell,1986,p7

Susan Wendall,Oppression and Victimization :Choice and Responsibility :A Reader in Feminist Ethics,ed. Debra Shogan .Toronto:Canadian Scholar’s Press Inc,1993p284

Maggie Humm, The Dictionary of Feminist Theory. Columbus ,USA:OhioState UP,1990 p10

Terry Eagleton, Literary Theory -An Introduction .Oxford :Basil Blackwell publishers Ltd,1983 p79

Trilokinath Raina ,Mahjoor and after , An Anthology of Modern Kashmiri Poetry .Delhi Sahitya Academy,2008p132

Irigaray The feminist Reader :Essays in Gender and the politics of Literary Criticism ed.C.Belsey and J.Moore.Basingstoke,1990p133

Jasbir jain,Growing Up as a women Writer- Transforming Gaze :Some Kashmiri Women poets.Delhi :Sahitya Academy,2007.p340

Neerja Mattoo,The Stranger Besides Me,Srinagar Gulshan Books, 2007 